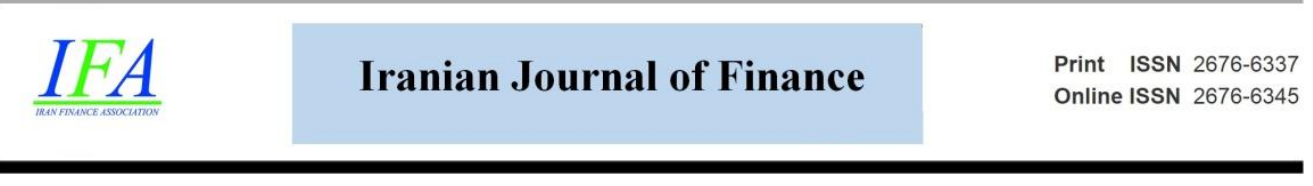

\title{
Asymmetric Reaction of Investors to Market Risk, Illiquidity Risk, and Credit Risk: Evidence from Tehran Stock Exchange (TSE)
}

\author{
Moslem Peymany* \\ *Corresponding Author, Assistant Prof., Department of Accounting, Faculty of \\ Management and Accounting, Allameh Tabataba'i University, Tehran, Iran. (Email: \\ m.peymany@atu.ac.ir)
}

\section{Amir Hossein Erza}

Assistant Prof., Department of Accounting, Faculty of Management and Accounting, Allameh Tabataba'i University, Tehran, Iran. (Email: ah.erza@atu.ac.ir)

\section{Farnaz Seifi}

Ph.D. Candidate, Department of Accounting, Faculty of Management and Accounting, Allameh Tabataba'i University, Tehran, Iran. (Email: farnaz_seifi@yahoo.com)

Document Type: Original Article

Received: 2020/03/04 Accepted: 2020/12/28

2020, Vol. 4, No. 4. 44-65

Published: 2020/12/28

\begin{abstract}
The relationship between risk and return is not symmetric under different circumstances. As the prospect theory describes, the value function which passes through the reference point is steeper for losses than gains (asymmetric risk appetite). But such an asymmetrical risk aversion could be traced in different periods of investment and market boom and bust cycles behind the reference point. Moreover, investors' asymmetric behavior is different regarding various risks, such as market risk, illiquidity risk, and credit risk. This paper examines the asymmetric investors' reaction to various risks in Tehran Stock Exchange (TSE) both in recession and growth from 2011 through 2016. Evidence reveals that although all three kinds of risks are relevant, especially illiquidity risk, risk factors' explanation power in the bullish market is less than the bearish one. This indicates that investors tend to show an asymmetric reaction to risk in up and downswing markets. The asymmetric behavior is also predominant due to investors' weak attention to the market risk in a growing market in opposition to a recessive market condition that turns out to be an important risk consideration. The results of this study can help investors to consider asymmetrical behavior effect when they are making their minds on investment decisions.
\end{abstract}

Keywords: Market Risk, Illiquidity Risk, Credit Risk, Asymmetric Reaction.

DOI: 10.30699/iif.2020.121531

Publisher: Iran Finance Association

Copyright: author(s)

Type of License: Creative Commons License (CC-BY 4.0) 


\section{Introduction}

Risk, return, and their relationship are key factors in the process of investment decision-making. Investors usually tend to avoid risk, and simultaneously move to maximize return. Theories indicate that returns should change along the time and these changes increase the investment risk. Various studies have presented evidence on this point (Sadat, Abbasi \& Ghalibaf Asl, 2020). Investors, in other words, are risk-averse in an efficient market and would invest in risky securities only if they gain a higher amount of return than usual. Mathematical interpretation is that a security price function is reversely related to risk and directly to return.

As expected, utility theory states, the amount of risk aversion differs based on utility function specified for each individual, but Kahneman and Tversky (1979) criticized expected utility theory as a descriptive model of decision-making under risk and developed an alternative model called prospect theory. They showed that people contribute to risk aversion in choices involving sure gains, and contribute to risk seeking in choices involving sure losses; therefore, the value function is normally concave for gains, commonly convex for losses, and generally steeper for losses than for gains (asymmetric risk appetite).

The prospect theory and its results are relevant to different periods of investment, i.e. investment in the period of recession and market boom. Accordingly, investors are risk-seeking and do not pay much attention to risks during the market boom, and are risk-averse during the market recession. The literature suffers lack of examination of the impact of risk on return, as well as its impact on the degree and severity of risk aversion in different market conditions (see Bheenick \& Brooks, 2015; Jang, Kang, \& Lee, 2012; Acharya \& Pedersen, 2005; Whitelaw, 2000); when faced with uncertainty, investors have been shown to behave according to prospect theory: Preferences are reference-dependent and exhibit loss aversion, and probabilities are subjectively weighed. A higher degree of loss aversion implies a higher subsidy to energy efficiency. Numerical simulations suggest that the impact of prospect theory on a policy may be substantial (Heutel, 2019). The quality of the relationship between return and risk is not the same in different markets. Many researchers, such as Friedman and Sandroff (2002), believe that the conditional fluctuations in return are time-dependent. This leads to important approaches called asymmetry or leverage effect on risk. Under such approaches, the risk is divided into two groups during market recession and boom, such that periods of recession or boom of the same length may have a 
different effect on conditional fluctuations.

The impact of different types of risks on return and respectively their comparison to determine the one which has the greatest impact on return in different market conditions has not been investigated in the current literature. This study, then, examined the asymmetric reaction of investors to market risk, illiquidity risk, and credit risk by taking into account market conditions in each bullish and bearish market to identify the most important risk causing asymmetrical behaviors.

According to the critical role and complexity of risk and return, it is necessary to investigate the relationship deeply; it seems that analysts and active institutions in the market are craving for a thorough and extensive knowledge about such a relation. So far, studies on the subject of research with this precision and detail, in the assessment of the impact of various types of financial risks, by dividing the general term of risk into three detailed categories of market risk, illiquidity risk and credit risk, as well as the division of the time period in bullish and bearish market conditions, conflation the prospect theory with the asymmetric reaction of investors to measure the reaction of investors to each of these risks in two periods of recession and boom in order to determine the main cause of asymmetric response to risk is not carried out either outside and inside of Iran. So, the subject of this article is innovative. The current study analyzed behaviors and asymmetric reactions of the market participants under various financial risks in different periods, growing and recessive market conditions, and showed the degree of importance and the influence of market, illiquidity, and credit risks on return more practically and coherently.

Extensive literature review about different risk classes have been done, and it is presented to draw a better picture of asymmetric behavior. Then the research methodology is described, and finally, the results are discussed and conclusions are made.

\section{Literature Review}

Simply put, investors aim to maximize expected return. Investment return is important for investors because all investment activities are geared towards making a return (Jones, 2006). Although they always aim to reduce risk in order to maximize return, there is a wide variety of risks involved in the investment process, and market risk, illiquidity risk, and credit risk are the most important ones. 


\section{Prospect Theory}

Based on Kahneman and Tversky's (1979) prospect theory, Barberis et al. (2001) demonstrated that investors are loss-averse about individual stock price fluctuations. In a later paper, in 2008, these authors also saw: (1) A positive relationship between expected returns and IVO; and (2) that investors applied the prospect theory to both current and future gains and losses in anticipated portfolios. Henderson (2012), Barberis and Xiong (2009), and Hensand Vlcek (2011) demonstrated that investors are risk-averse after trading for a gain, but more cautious after trading for a loss, after which they tend to hold on to stocks whose prices have dropped. More recently, Barberis et al. (2016) showed that when investors make a decision to buy or sell equities, they initially represent them by the distribution of their past returns and then evaluate them using the prospect theory. Thus, based on the foregoing discussion, we assumed that a difference in investors' risk tolerance explains the negative relationship between VOL and future stock returns. Ang et al. (2006, 2009) called this the IVOL anomaly. Wang et al. (2016) also supported this view.

In this paper, we use Barberis et al.'s (2016) prospect theory to define investors' risk attitudes in the Korean stock market. Also, Gregoriou, Healy, and Le (2019) showed that this holds that agents evaluate decisions under risk using a set of psychological criteria. This theory has become one of the most important descriptive alternatives to expected utility theory. There are four elements of prospect theory, including reference dependence, loss aversion, diminishing sensitivity, and probability weighting. An important testable proposition of the theory, with implications for asset pricing and market efficiency, is that one of these criteria is Reference Dependence in evaluating expected outcomes. To solve the consumption and portfolio choice problem of an individual, Bilsen \& Laeven have used prospect theory preferences featuring loss aversion, an endogenous reference level, and probability weighting, and analyzes how these features jointly impact the optimal consumption and portfolio strategies (Bilsen \& Laeven, 2019). In this case, Kahneman and Tversky (1979) stated that people make decisions based on the potential value of return rather than the outcome and that people evaluate these return using a reference point. This differs from expected utility theory, in which a rational agent is indifferent to the reference point because the value function passes through the reference point in the prospect theory, and we consider investors' reactions to risks asymmetrically by the prospect theory. 


\section{Market risk}

Market risk is defined as a decrease in an investment value because of adverse movements in market prices. There are many different approaches and alternative measures for financial risk.

Analysis sounds more real if it is based on undesirable risk measures. Undesirable risk measures represent the likelihood of price decline of an asset or investment, or the amount of loss caused by potential price reduction. An undesirable risk is the estimation of a potential reduction in prices of an asset during good market conditions or potential loss in an investment. In other words, it is a part of the risk that has a negative effect on investment. It should be noted that low- and high-risk stock return increase in the market downturn, high-risk stocks return increase in the market boom, and low-risk stocks return decrease in the market boom. This approach is based on the assumption that return and different reactions of investors to fluctuations below the average and fluctuations above the average are asymmetric.

Based on this framework, which is the basis of the modernization of portfolios, it is believed that investors consider movements below the risk as a return and upward movements as an opportunity. Therefore, investors who attach great importance to undesirable risk require a risk premium to hold assets that have a lower return. It could be concluded that assets with a skewness are negative, i.e. they are more likely to cause damage. In other words, their downward return has a higher absolute magnitude than their upward return. These assets are less attractive to investors and require higher return and less pricing. Conversely, positive assets are more attractive and less risky.

Two of the most common methods for quantifying the undesirable market risk are Value at Risk (VaR) and Conditional Value at Risk (CVaR) (Chornous \& Ursulenko, 2013). The basis for the VaR evaluation is the price tool dynamics for a specified time in the past. To explain the exact meaning of $\mathrm{VaR}$ and $\mathrm{CVaR}$, let $\mathrm{X}$ be the return of security with the cumulative distribution function of $F_{X}(\mathrm{z})=\mathrm{P}\{\mathrm{X} \leq \mathrm{z}\}$. By definition, $\operatorname{VaR}_{\alpha}(\mathrm{X})$ is a lower $\alpha$-percentile of the random variable $X$. Then, VaR of $X$, with a confidence level of $\alpha \in$ $[0,1]$, is

$$
\operatorname{VaR}_{\alpha}(\mathrm{X})=\min \left\{\mathrm{z} \mid F_{X}(\mathrm{z}) \geq \alpha\right\}
$$

An alternative percentile measure of risk is Conditional Value-at-Risk (CVaR). The term was introduced by Rockafellar and Uryasev (2000). For random variables with continuous distribution functions, $\mathrm{CVaR}$ is a conditional 
expectation of $X$ subject to $X \geq V a R$. Then the $C V a R$ of $X$, with a confidence level of $\alpha \in[0,1]$, is the mean of the generalized $\alpha$-tail distribution:

$\mathrm{CVaR}_{\alpha}=\int_{-\infty}^{\infty} \mathrm{zdF}_{\mathrm{x}}^{\infty}(\mathrm{z})$

Where

$\mathrm{F}_{\mathrm{X}}^{\alpha}(\mathrm{z})= \begin{cases}0, & \text { when } \mathrm{z}<\operatorname{VaR}_{\alpha}(\mathrm{X}), \\ \frac{\mathrm{F}_{\mathrm{X}}(\mathrm{z})-\alpha}{1-\alpha}, & \text { when } \mathrm{z} \geq \operatorname{VaR}_{\alpha}(\mathrm{X}) .\end{cases}$

It is necessary to say that investors react differently to market risk in miscellaneous situations. For instance, Whitelaw (2000) investigated this issue in a general equilibrium exchange economy characterized by a regimeswitching consumption process with time-varying transition probabilities between regimes. When it is estimated using consumption data, the model generates a complex, non-linear, and time-varying relation between expected return and volatility, duplicating the salient features of the risk/return trade-off in the data. The results emphasize the importance of time-varying investment opportunities and highlight the perils of relying on intuition in static models. In another research, Dicle (2018) asserted that when market risk is above longterm averages, investors would be expected to react more strongly compared to days when market risk is below market averages. When the market risk is above long-term averages, investors become more responsive to changes in risk (possibly more prone to panic). Hoang, Wong, and Zhu (2015) showed that in general, risk-averse investors prefer not to include gold while riskseeking investors prefer to include it in their stock-bond portfolios. Furthermore, risk-seekers prefer including gold in an equal-weighted portfolio while risk-averters prefer including gold in efficient portfolios. They used the modified value-at-risk approach to examine this issue. In this regard, Jorion (2000) proposed using Value-at-Risk (VaR) and Rockafellar and Uryasev (2000) recommend using the conditional-VaR (CVaR). Escobari and Jafarinejad (2019) showed that investors' uncertainty is greater during economic downturns, and it is linked with lower investors' sentiment. Besides, the results supported the existence of a positive conditional correlation between sentiment and returns. This positive spillover between sentiment and returns was interpreted as a positive link between investors' uncertainty and market risk. The authors also found that investors' uncertainty and market risk were strongly driven by their lagged values. The authors' measure consistently captured periods of high uncertainty as shown by a positive and highly statistically significant correlation with other existing measures of uncertainty. 


\section{Illiquidity risk}

Another factor affecting asset risk is the ability to liquidate it. Liquidity involves the ability to trade in a sufficient volume without negatively affecting the price confidently. The absence of any of these factors renders asset illiquidity - to some degree - and the additional return an illiquid asset offers the investor over a liquid alternative (Jecks, 2016). Intuitively, illiquidity refers to the degree of the effect of order flow on the stock price. Based on this, Amihud (2002) calculated the risk of illiquidity. This ratio, indeed, captures the essence since it reflects the change in return caused by the transaction of one unit of money. The daily illiquidity measure for each stock is computed based on volume and return as follows:

Illiquidity $_{\mathrm{s}, \mathrm{t}}=\frac{\left|\mathrm{R}_{\mathrm{s}, \mathrm{t}}\right|}{\mathrm{Vol}_{\mathrm{s}, \mathrm{t}}}$

Where $R_{s, t}$ is the return of stock $s$ at day $t$ and $\mathrm{Vol}_{s, t}$ is the volume of stock trade $\mathrm{s}$ at day $\mathrm{t}$. The issue of illiquidity risk has been raised as a determinant of stock return since the mid-1980s. Some researchers, such as Baker, Stein, and Wurgler (2003) found a positive relationship between stock return and liquidity, while others, such as Omari, Ziyani, and Loukil (2004) declared that the relationship between these two variables is negative. In addition to these studies, some showed different reactions to illiquidity risk in different conditions. For example, equity holdings experience a higher liquidity risk during the recession in comparison with growth while rising stocks are opposite, which means that their liquidity risk is higher when the market is growing. Moreover, during the recession, small value stocks are more liquid than small growth stocks, and when stock market booms, small growth will be more liquid than the small value stock.

Jang, Kang and Lee (2012) proposed a simple way to capture the multidimensionality of liquidity. Their analysis indicates that existing liquidity measures have considerable asset-specific components, which justifies their approach. Constructing a two-factor model with the market and liquidity factors, this paper concluded that the two-factor model explains the crosssection of stock return in Korea from 1987 to 2010, describing the liquidity premium, size, and value effects. However, the CAPM and Fama-French threefactor model fails to do so. Their results also showed that the role of the illiquidity risk in expected stock return is especially pronounced during the post-Asian financial crisis period.

Drechsler, Moreira, and Savov (2018) showed, both theoretically and 
empirically, that liquidity creation induces negative exposure to volatility risk. Intuitively, liquidity creation involves taking positions that could be exploited by privately-informed investors. These investors ability to predict future price changes makes their payoff resemble a straddle (a combination of call and put). By taking the other side, liquidity providers are implicitly short of a straddle, suffering losses when volatility spikes. Empirically, they showed that shortterm reversal strategies, which mimic liquidity creation by buying stocks that go down and selling stocks that go up, have a large negative exposure to volatility shocks. The effect of illiquidity shocks on asset prices has not been studied well, except for one paper which implied that the required rates of return should be higher for relatively illiquid securities (Brennan \& Subrahmanyam, 1996). Therefore, investors' reaction to securities with the highest risk of illiquidity is higher, and investors expect higher rates of return from these securities. They investigated the empirical relationship between monthly stock return and measures of illiquidity obtained from intraday data. They found a significant relationship between the required rate of return and illiquidity in stock return.

Petkova, Akbas, Boehmer, and Genc (2010) investigated the time-varying liquidity risk of value and growth stocks. They found value stocks are riskier when the market is in recession, while this is opposite for growth stocks. This study also showed that in a recessive market, small value stocks are more liquid than small growth stocks, and during the booming time the latter is more liquid than the former. Their research suggested that investors are keen to sell value stock intensively comparing with growth ones during the recession; such behaviors would influence value stocks illiquidity respectively.

Bali, Peng, Shen, and Tang (2014) found that illiquidity shock has a significant impact on asset prices. In particular, they showed that a positive illiquidity shock is associated with a lower future stock return up to six months and vice versa. This negative relation between illiquidity shocks and stock return also could not be explained by existing asset-pricing models. They proposed a behavioral explanation and argued that the illiquidity shock effect is more consistent with the reaction hypothesis. Chen and Wei (2017) examined market reactions to positive and negative illiquidity shocks separately. They found that negative illiquidity shocks generate return continuation while positive illiquidity shocks lead to initial return continuation, but quickly followed by a return reversal; the latter return pattern determines the duration of the total effect of illiquidity shocks. Further analysis shows that the underreaction channel proxies with institutional ownership only work well in stocks with negative illiquidity shocks. In contrast, the illiquidity spiral channel 
proxies by short-term versus long-term institutional ownerships are strongly supported in stocks with positive illiquidity shocks. Pengcheng Song and Zhang (2019) showed significant and negative liquidity risk premium in period 3 (2007-2016), whether in subsamples or the full sample. In the full sample test, the liquidity risk premium display statistically significant and negative effect. In the subsample test, it also displayed the statistically significant and negative liquidity risk premium in period 3 and the full period. Namely, it always displays the negative liquidity risk premium, which demonstrates investors' lack of concern about compensation for the liquidity risk they suffered, even paying a liquidity risk premium to buyers, to sell their stocks as soon as possible. In addition, they found significant and negative liquidity risk premium in period 3 (2012-2016) and the full period (2002-2016) of low- DY companies. The result also shows the liquidity and market factor model has more significant value, which performs better than liquidity and the FamaFrench three-factor model.

\section{Credit risk}

The other kind of risk is credit risk. The probability of default in obligations is called credit risk (Damodaran, 2013). Credit risk could be quantified by credit rating. Credit rating is the assessment of timely payment of publishers' financial obligations. In other words, this ranking is a statement about forecasting credit rating of an institution, a credit obligation, a debt statement, security, or a publisher itself. Credit rating is a relative measure for credit risk based on quantitative and qualitative analysis of various factors and variables (Murcia, Dal-Ri Murcia, Rover, Borba, 2014). Identifying indicators affecting credit risk becomes a significant issue; one of the success factors of credit decisions is the correct selection of effective credit risk indicators for an accurate and a complete evaluation.

A positive relationship is expected to exist between credit risk and expected return. However, uncertainty lies in credit risk and realized return relationship on the grounds that there is a negative relationship between credit risk and stock market return. That is, companies with a higher credit risk grade may own less return than those with the lower one (Bheenick \& Brooks, 2015). Also, there is some, but not comprehensive, evidence for the existence of an asymmetric relationship between credit risk and return based on different criteria. For example, Freitas and Minardi (2013) studied whether credit rating downgrades and upgrades have a significant effect on the price of Latin American stocks. They analyzed stock market reactions to news of the four major markets of Latin America, including Argentina, Brazil, Chile and 
Mexico. Findings indicate that credit rating downgrades have a significant impact on the market responsiveness, while this effect is far lower in raising credit ratings.

Habib et al. (2015) investigated the impact of credit ratings on the stock return of 22 active banks ranked by the Pakistan Ranking Authority in the Karachi Stock Exchange. The results indicate that credit ratings do not have a significant effect on the abnormal return of banks. Also, the response of stock return to promotion and credit rating degradation was measured in this research. As a result, credit rating downgrade leads to a significant and positive response, and an upgrade of credit rating leads to an unnecessary negative response. Bissoondoyal, Bheenick and Brooks (2015) specifically examined the assessment of credit risk and return on equity in companies with high and low risks that are listed in the Australian and Japanese stock markets from January 1990 until June 2012. The results show that stock market return for companies with high and low credit qualities has a similar pattern in developed markets. Companies with higher credit ratings (low credit risk) have a higher return than low-rated companies, which should be more productive for more risk-taking investors.

Dud, Vo Hong, Thien, and Dinh (2013) rated 643 companies listed by Vietnam Stock Exchange regarding their reported financial ratios including liquidity, efficiency, capital structure and leverage, profitability, assets structure, and growth rate (earning and profit after tax) ratios. Gumparthi, Khatri, and Manickavasagam (2011) included four main categories- industry risk, commercial risk, financial risk, and management risk- in their study to design and formulate a credit rating framework for public sector banks in India. They determined the weight of each category based on professionals', managers of credit rating institutions, understandings and judgments by utilizing a survey and discriminant analysis; results present that weighted average model is proper for evaluation of companies' credit rating because of its higher forecasting power.

Hwang et al. (2010) examined credit rating with 29 variables related to market, financial, and industrial factors. Tansel and Yardakul (2010) rated companies and industries in Turkey by fuzzy TOPSIS technique. They first rated industries regarding the economic and industrial macro variables, and respectively analyzed companies' financial ratios with fuzzy TOPSIS. Finally, they combined result from both ratings to obtain a unified and comprehensive metric; researchers also compare their findings with what professionals think, understand, and assume about companies' credit grade; interestingly they 
observed little deviation from their quantitative analysis. Chikolwa and Chan (2008) rated Australian companies with total assets and debts, total debts to total assets, short-term debts to total assets, current ratio, costs before profit interest, and operational profit (margin). Marcin and Tomasz (2009) applied data envelopment analysis to rate 1408 companies. Their data input was total debt ratio, current debt to net sales, and financial costs to net sales, and net sales to equity, capital adequacy ratio, and equity to asset were the output of the model. Bone and Ribeiro (2009) examined the impact of rating changes on the Brazilian stock market from 1995 to 2007. They investigated whether rating change announcements affect systematic risk measured by beta. They used the Chow stability test and found no evidence of structural breaks before or after the change. Byström (2018) demonstrated a close relationship between credit-implied stock return expectations and future realized stock return.

There exist researches that aim different perspectives to analyze direct and indirect effects of financial risks especially credit and liquidity risks, over either banks or companies. As a case in point, Mwaurah, Muturi and Waititu (2017) investigated the influence of financial risk on stock return. The stock return data of 9 banks listed from 2006 to 2015 was used as the dependent variable, while credit risk, market risk, liquidity risk, and capital risk were used as independent variables. Bank size was used as a control and moderator variable. Individual regression of credit risk, market risk, liquidity risk, and capital risk showed a statistically significant positive relationship with stock return. Collective multiple GLS regression of financial risk with a control variable of bank size indicated financial risk is negatively significant on stock return while bank size had a positive significant influence on stock return. The moderating effect of bank size on the influence of financial risk on stock return was found positively significant.

Akhavi and Mehri (2015) investigated the effects of financial risks on the relationship between earnings per share and stock return. The findings indicated that there is a positive and significant relationship between earnings per share and stock return.

Sobia, Arshad, and Szabo (2015) executed a study to investigate the effect of financial risk on the sensitivity of stock return. The stock return was used as the dependent variable, while the independent variable of financial risk was represented by interest rate, exchange rate, financial exposure, and total risk. Firm size was employed as a control variable. The study findings conclude that interest and exchange rates at industry and firm-level hold a negative significant relationship with a stock return while total risk, growth rate, firm 
size and financial exposure was insignificant on industry and firm level. Interest rate holds a positive significant relationship on stock return for exporting and non-exporting, while exchange rate holds a negative significant relation for the same group.

As mentioned above, all main risk categories (market, illiquidity and credit risks) are factors affecting investors' view and could have different effects on return, showing an asymmetry in market investors' behavior. Accordingly, the present study aims to investigate the importance of different risks and inspect probable asymmetric behavior toward all three risk categories based on market conditions. Moreover, inspired by Kahneman \& Tversky (1979), it's known that reaction to risk could change based on variant states. In this regard, the second goal of this paper is to investigate whether market reaction toward risk is changed in various market circumstances and if so, which one of these three risks categories causes this.

\section{Methodology and Data Analysis}

This part sets out the methodology adopted in this study, and it presents the data analysis. A descriptive design is employed in this study since it seeks to analyze the relationship between risk and return in different market conditions in TSE. The population of this research consists of all stocks listed in TSE. TSE market value was 80 billion US dollars in 2016, and it is the largest capital market in Iran. There are more than 320 active companies in 40 industrial sectors; TSE is not limited to equity; that is, other financial instruments like debt securities, Sukuk, ETF, futures, and options are actively traded by natural persons and institutions, e.g., investment companies and mutual funds. International capital markets are not influential to TSE indices and price1; these are usually influenced by international commodity prices and national economic factors.

The study employs secondary data from TSE. The data includes daily logarithmic return, the daily value of trades and financial statements to calculate credit ratings ${ }^{2}$ of companies listed in $\mathrm{TSE}^{3}$ from March 26, 2011, to

\footnotetext{
${ }^{1}$ TSE monthly return regression determination coefficient to S\&P500 is 0.003492 which is meaningless.

2 Although the credit rating of companies in developed countries is done by rating agencies, TSE lacked such institutions. Therefore, to rank companies based on credit risk, credit rating determinants were first identified based on literature and then, these determinants were
} 
March 16, 2016. Using these data, standard deviation, value at risk and conditional value at risk were historically calculated for quantifying the market risk criteria. Also, based on the daily return and the value of transactions during this period; the Amihud index was calculated as an indicator for measuring illiquidity risk. This paper uses return measures as dependent variables and illiquidity risk, market risk, and credit risk as independent variables. In multiple regression analysis, the model for linear regression was extended to account for the relationship between the dependent variable (stock return) $R_{i, t}$ and the three independent variables of mean market risk, illiquidity risk, and credit risk. The general form of the multiple regression models is

$R_{i t}=\beta_{0}+\beta_{1}$ MarketRisk $_{i t}+\beta_{2}$ IlliquidityRisk $_{i t}$

$+\beta_{3}$ CreditRisk $_{i t}+\epsilon_{i t}$

The parameters of the model are $\beta_{0}, \beta_{1}, \beta_{2}$ and $\beta_{3}$, and $\epsilon_{i t}$, which is the error term. Just as conventional regressions, panel data approach is used based on redundant fixed effects test and Hausman test ${ }^{4}$, and corrections were made according to the classic assumptions of regression if it was necessary.

By dividing 5 years interval into two 2-year periods (after the elimination of 2011 where there wasn't a specific trend in the total index of TSE), the analyses of each part were done in two sub-periods of the market boom (2012 and 2013) and market downturn (2014 and 2015) to analyze the behavioral asymmetry among investors.

It is necessary to select one of the three criteria for market risk (standard deviation, value at risk or conditional value at risk) during data analysis. For such a purpose, the simultaneous effect of these three criteria on the overall return of the 5 years and every two sub-periods separately are examined in panel A of Table 1.

weighted and credit ranking of each company was calculated according to a survey questionnaire (by TOPSIS method and based on Friedman test).

${ }^{3}$ Listed companies are active in petrochemical, metals, medical, cement, food, automotive industries and so on

${ }^{4}$ Each regression, in addition to the OLS method, is also estimated by GMM, if possible; but no significant change is found in the final results. Therefore, to summarize the content, only the results of the OLS method are displayed. 
Table 1. Comparison of the effect of different market risk factors on return

\begin{tabular}{|c|c|c|c|c|c|c|}
\hline & \multicolumn{4}{|c|}{ Panel A } & Panel B & Panel C \\
\hline Constant & $-0.45421^{* * *}$ & $0.567106^{* *}$ & $0.505639^{*}$ & $0.723673^{*}$ & -0.19922 & -0.06096 \\
\hline $\begin{array}{c}\text { Standard } \\
\text { Deviation }\end{array}$ & -0.00016 & $5.93 \mathrm{E}-05$ & --- & --- & -0.00016 & $0.03219^{* *}$ \\
\hline VaR & $-0.44692^{* * *}$ & --- & -0.023 & --- & $0.31311^{* *}$ & $0.27206^{-}$ \\
\hline $\mathrm{CVaR}$ & $0.073622^{* * *}$ & --- & --- & $0.06155_{*}^{* *}$ & $\underset{*}{0.034788}$ & $0.107046^{* *}$ \\
\hline R-squared & 0.186268 & --- & --- & --- & 0.082755 & 0.187545 \\
\hline
\end{tabular}

Notes: Return regressions based on three criteria of market risk (standard deviation, value at risk and conditional value at risk) are presented for three periods (all data from 2011 to2015: panel A, prosperity period from 2012 to 2013: panel B, the period of recession from 2014 to 2015: Panel C).

The figures marked with ***, and $* * *$ indicate significant coefficients in 90, 95 and $99 \%$ confidence intervals, respectively.

As can be seen, the estimated coefficient for the standard deviation is not significant when the impact of all three criteria on return is evaluated simultaneously in a single regression, but the value at risk and the conditional value at risk has significant coefficients (-.44692 and .073622, respectively). Also, in the separate regressions of these three risk metrics, the only criterion of the conditional value at risk is significant (.06155). Therefore, among these three criteria of market risk, the criterion of conditional value at risk is used as a measure for market risk ${ }^{5}$. This is consistent with the theoretical foundations referred to in the previous section, indicating theoretical superiority of conditional value at risk over standard deviation and value at risk. This is consistent with other similar investigations such as Sarykalin, Serraino \& Uryasev (2008) ${ }^{6}$.

After selecting an appropriate market risk criterion, the impact of all types of risks under investigation (market risk, illiquidity risk and credit risk) on return is examined. In this section, surveys have been conducted in three

\footnotetext{
5 Another approach is to use a combination of three factors using methods such as principal component analysis (PCA), which is also examined, but finally, CVaR is used based on the explanatory power benchmark.

${ }^{6}$ Using CVaR instead of standard deviation is preferred based on normality tests of return distributions (Jarque-Bera test and Kolmogorov- Smirnov test) that rejected normality assumption.
} 
periods, including the entire course, the market boom period, and the recession period. The results are presented in Table 2, in three separate panels. Also, in each panel, a regression consisting of all three types of risks, and three regressions for each of the risks is separately estimated.

Table 2: Comparison of the effect of market risk, illiquidity risk and credit risk on return

\begin{tabular}{|c|c|c|c|c|}
\hline \multicolumn{5}{|c|}{ Panel A } \\
\hline Constant & $-2.05001^{* * *}$ & $0.723673^{* * *}$ & $0.354252^{* * *}$ & $-1.35409^{* * *}$ \\
\hline $\mathrm{CVaR}$ & $0.040935^{\text {*** }}$ & $0.06155^{* * *}$ & --- & --- \\
\hline Illiquidity & $480.5734^{* * *}$ & --- & $363.1677^{* * *}$ & $\begin{array}{ll}-- \\
--\end{array}$ \\
\hline Credit Risk & $6.266727^{* * * *}$ & --- & --- & $4.938926^{* * * *}$ \\
\hline R-squared & 0.253092 & 0.106277 & 0.161777 & 0.116052 \\
\hline Akaike & 3.301986 & 3.473596 & 3.409484 & 3.462598 \\
\hline Schwarz & 4.173776 & 4.328781 & 4.264669 & 4.317783 \\
\hline Hannan-Quinn & 3.643785 & 3.808885 & 3.744773 & 3.797887 \\
\hline \multicolumn{5}{|c|}{ Panel B } \\
\hline Constant & -1.20013 & $0.596224^{* * * *}$ & $0.418519^{* * * *}$ & -0.33334 \\
\hline $\mathrm{CVaR}$ & 0.033883 & 0.024263 & --- & -- \\
\hline Illiquidity & $386.1953^{\text {*** }}$ & --- & $203.9272^{* *}$ & --- \\
\hline Credit Risk & $4.138677^{* *}$ & --- & --- & 2.209965 \\
\hline R-squared & 0.075754 & 0.00793 & 0.024087 & 0.010179 \\
\hline Akaike & 2.965441 & 3.016649 & 3.000228 & 3.014379 \\
\hline Schwarz & 3.030502 & 3.049179 & 3.032759 & 3.046909 \\
\hline Hannan-Quinn & 2.99176 & 3.029808 & 3.013388 & 3.027538 \\
\hline \multicolumn{5}{|c|}{ Panel C } \\
\hline Constant & -0.15965 & $0.862157^{\text {**** }}$ & $0.284447^{* * *}$ & -0.51178 \\
\hline $\mathrm{CVaR}$ & $0.101169^{* * *}$ & $0.118527^{* * *}$ & --- & --- \\
\hline Illiquidity & $389.222^{* * *}$ & --- & $382.2088^{* * * *}$ & --- \\
\hline Credit Risk & 1.736365 & --- & --- & $2.861449^{* *}$ \\
\hline R-squared & 0.292196 & 0.081858 & 0.200609 & 0.029723 \\
\hline Akaike & 2.721777 & 2.962354 & 2.823853 & 3.017584 \\
\hline Schwarz & 2.786839 & 2.994885 & 2.856384 & 3.050114 \\
\hline Hannan-Quinn & 2.748096 & 2.975513 & 2.837012 & 3.030743 \\
\hline
\end{tabular}

Notes: Return regression is carried out based on three criteria for market, illiquidity and credit risks over three periods (the general period from 2011 to 2015: panel A, prosperity period from 2012 to 2013: Panel B, the period of decline from 2014 to 2015: Panel C).

The figures marked with $* * *$, and $* * *$ indicate significant coefficients in 90,95 and $99 \%$ confidence intervals, respectively. 
Results of the estimated regressions are first analyzed based on the total 5-year period. Panel A data show when the impact of all three types of risks on return was evaluated simultaneously or when each risk was analyzed separately, the coefficients of all three risks were significant with a positive sign. According to the criteria for regressions goodness of fit for each factor (R-Squared, Akaike, Schwarz and Hannan-Quinn), the explanatory power of illiquidity risk is more than two other risks. Therefore, generally illiquidity risk is more important than other risks although all three risks are of interest, and investors request risk premium for them. When we narrow our analysis to the market boom (Panel B), the results will become somewhat different. In this period, it seems that investors do not pay much attention to market risk. This could be seen in the simultaneous regression of each of the three risks and also in the individual regressions in Panel B. In this case, again, the illiquidity risk is the most important and has the most explanatory power.

During the recession, there is an important change in how investors deal with all kinds of risks. As can be seen in Panel $\mathrm{C}$, in the period of recession and simultaneously reviewing each of the three risks, the market risk is of a significant coefficient even at 99\% confidence interval (.101169), along with a significant risk factor of illiquidity (389.222). However, credit risk in this period does not have a significant coefficient in regression. In assessing the separate regressions in this period, market risk and illiquidity risk are significant at a $99 \%$ confidence level, but credit risk is just significant at $95 \%$ confidence level $(2.861449)^{7}$.

Three factors in the growth and recession period would indicate that the three risk factors have less explanatory power during the boom period than recession period when two regressions are simultaneously compared. In other words, investors have an asymmetric reaction toward risk during the boom and recession periods, and they are paying more attention to risk factors during the downturns, which is generally due to increased market interest as a result of market risk. More precisely, investors are less risk-averse and not attentive to risk factors in the boom period. However, during the recession period, the degree of risk aversion of investors has increased, and they pay more attention to all three types of risks, in particular, the illiquidity risk and market risk, which is similar to prospect theory in Kahneman and Tversky (1979).

7 The effects of the market trend changes periods were analyzed by dummy variables but results show that the effect is statistically insignificant. 


\section{Conclusion and Discussion}

Based on expected utility theory, individuals are risk-averse in the presence of risky outcomes, this means that the individual would refuse a fair game. In this situation, based on a utility function, investors will choose one investment opportunity over another if and only if the expected utility of one exceeds that of the other. But, Kahneman and Tversky (1979) stated that people make decisions based on the potential value of return rather than the final outcome and that people evaluate these return using a reference point. This differs from expected utility theory, in which a rational agent is indifferent to the reference point because the value function passes through the reference point in the prospect theory, and it is steeper for losses than gains, indicating that losses outweigh gains. In simple words, investors react to risks asymmetrically and their risk aversion in the loss region is less than gain region.

According to this asymmetric behavior and other evidence mentioned in this research, by dividing the general term of risk into three detailed categories of market risk, illiquidity risk and credit risk, individual reactions to these risk factors are studied in bullish and bearish market conditions. The population of this research consists of all stocks listed in TSE. The study employs secondary data from TSE. The data includes daily logarithmic return, the daily value of trades and financial statements to calculate credit ratings8 of companies listed in TSE9 from March 26, 2011, to March 16, 2016. By dividing 5 years interval into two 2-year periods, the analyses of each part were done in two sub-periods of the market boom (2012 and 2013) and market downturn (2014 and 2015) to analyze the behavioral asymmetry among investors. The results are presented in Table 2, in three separate panels. Also, in each panel, a regression consisting of all three types of risks, and three regressions for each of the risks is separately estimated.

The first purpose of this paper is to determine which of the three risk factors had a greater impact on stock return. The other and more important purpose is to measure the reaction of investors to each of these risks in two

\footnotetext{
8 Although the credit rating of companies in developed countries is done by rating agencies, TSE lacked such institutions. Therefore, to rank companies based on credit risk, credit rating determinants were first identified based on literature and then, these determinants were weighted and credit ranking of each company was calculated according to a survey questionnaire (by TOPSIS method and based on Friedman test).

${ }^{9}$ Listed companies are active in petrochemical, metals, medical, cement, food, automotive industries and so on.
} 
periods of recession and boom in order to determine the main cause of asymmetric response to risk. So far, studies on the subject of research with this precision and detail are not carried out either outside and inside of Iran. So, we can say that the subject of this article is innovation. So this article can be an example of innovation in this topic.

The results suggest that all three risk categories are of investors', who request a premium for them, interest; however, illiquidity risk is more important than other risks. The results are somewhat different when the analysis is limited to the market boom period. In this period, it seems that investors do not pay much attention to market risk. In this case, again, illiquidity risk is the most important risk; during the recession, there is a noteworthy change in the market reaction to the risk categories. In the period of recession, market risk, like other risks, has a significant effect on return. Another interesting result about the comparison of boom and bust periods is different explanatory powers of risk factors. Results indicate that the three risk factors have less explanatory power during the boom period relative to the recession period; investors have an asymmetric risk aversion behavior during these times and the downturn, and they pay more attention to risk factors mainly due to increase in market risk.

The results of the study help analysts to consider asymmetrical behavior effect when they are making their minds on investment decisions. Future investors may also benefit from findings because those draw a clearer picture from what investors would do under different market circumstances, namely market recession and growth. Such researches could more practically delineate the importance of market, illiquidity, and credit risks and their effects on return when boom and bust cycles are included and analyzed separately. Future studies could shed light on the subject from various perspectives. First, they could employ such frameworks, and test probable asymmetric behavior of risks in other markets under their specific conditions. Another proposition could be based on creating a portfolio based on three risk factors and analyzing returnrisk relation.

Funding: This research received no external funding. 


\section{References}

Akhavi Babi, Mehri (2015). The effects of financial risks on the relationship between earnings and stock return. International Journal of Organizational Leadership 4(2015) 154-169.

Amihud, Yakov, 2002, Illiquidity and stock return: Cross-section and time-series effects, Journal of Financial Markets 5, 31-56.

Ang, A., Hodrick, R.J., Xing, Y., Zhang, Z., 2006. The cross-section of volatility and expected returns. J. Finance 61 (1), 259-299.

Ang, A., Hodrick, R.J., Xing, Y., Zhang, X., 2009. High idiosyncratic volatility and low returns: International and further US evidence. J. Financ. Econ. 91 (1), 1-23.

Baker, Malcolm. Stein, Jeremy C. Wurgler, Jeffrey. (2003). When Does the Market Matter? Stock Prices and the Investment of Equity-Dependent Firms. The Quarterly Journal of Economics, Volume 118, Issue 3, 1 August 2003, Pages 9691005.

Bali, T., L. Peng, Y. Shen, and Y. Tang, 2014, Liquidity shocks and stock market reactions, Review of Financial Studies 27, 1434-1485.

Barberis, N., Huang, M., Santos, T., 2001. Prospect theory and asset prices. Q. J. Econ. 116, 1-53.

Barberis, N., Xiong, W., 2009. What drives the disposition effect? an analysis of a long-standing Preference-Based Explanation. J. Finance 64 (2), 751-784.

Barberis, N., Mukherjee, A., Wang, B., 2016. Prospect theory and stock returns an empirical test. Rev. Financ. Stud. 29 (11), 3068-3107

Bilsen, Servaas van \& Laeven, Roger J. A. (2019). Dynamic Consumption and Portfolio Choice under Prospect Theory. Available at SSRN: https://ssrn.com/abstract=3398873 or http://dx.doi.org/10.2139/ssrn.3398873

Bissoondoyal-Bheenick, Emawtee \& Brooks, Robert (2015). The credit riskreturn puzzle: Impact of credit rating announcements in Australia and Japan. PacificBasin Finance Journal 19 (35), 37 - 55

Bone, R. B., \& Ribeiro, E. P. (2009). Conteúdo informacional dos ratings corporativos deempresas brasileiras, 1995-2007. Proceedings of the Brazilian Finance Meeting. São Leopoldo, Brazil, 9.

Brennan, Michael J. Subrahmanyam, Avanidhar (1996). Market microstructure and asset pricing: On the compensation for illiquidity in stock return. Journal of Financial Economics Volume 41, Issue 3, July 1996, Pages 441-464.

Byström, Hans (2018). Stock return expectations in the credit market. International Review of Financial Analysis Volume 56, March 2018, Pages 85-92. 
Chen, Te-Feng. Wei, K.C. John (2017). Illiquidity Shocks and Asymmetric Stock Market Reactions Around the World: Is Underreaction or Illiquidity Spiral the Culprit? Available at

SSRN: https://ssrn.com/abstract=3056151 or http://dx.doi.org/10.2139/ssrn.3056151

Chikolwa, B. and Chan, F. (2008). Determinants of commercial mortgagebacked securities credit ratings: Australian evidence. International Journal of Strategic Property Management. Vol. 12. pp. 69-94

Chornous, Galyna. Ursulenko, Ganna. (2013). Risk Management Inin Banks: New Approaches Toto Risk Assessment Andand Information Support. Ekonomika 2013 Vol. 92(1).

Damodaran, Aswat. Advanced Corporate Finance: An Appropriate Approach (2013). Tehran: publishers. Persian translation

Dicle, Mehmet F. Reed, Kendra. (2018) Asymmetric return response to expected risk: Regulatory response. SSRN.

Drechsler, Itamar and Moreira, Alan and Savov, Alexi, Liquidity Creation as Volatility Risk (March 2, 2018). Available at SSRN: https://ssrn.com/abstract=3133291 or http://dx.doi.org/10.2139/ssrn.3133291.

Dud, Vo Hong. Thien, Nguyen Dinh (2013). A new approach to determining credit rating \& its applications to Vietnam's listed firms. Available on https://www.murdoch.edu.au

Escobari, Diego \& Jafarinejad, Mohammad (2019). Investors' Uncertainty and Stock Market Risk. Journal of Behavioral Finance, DOI: 10.1080/15427560.2018.1506787.

Freitas, Abner de Pinho Nogueira \& Minardi, Andrea Maria Accioly Fonseca (2013). The Impact of Credit Rating Changes in Latin American Stock Market, Available online at http://www.anpad.org.br/bar

Friedman, R. \& Sanddrof-Kohle, W.G. (2002). Volatility Clustering and Nontrading Days in Chinese Stock Markets. Journal of Economics and Business, 54(2): 193-217.

Gregoriou, Andros \& Healy, Jerome V. \& Le, Huong (2019). Prospect theory and stock returns A seven-factor pricing model. Journal of Business Research. Volume 101, August 2019, Pages 315-322

Gumparthi S, Khatri S, Manickavasagam V (2011). Design and development of credit rating model for public sector banks in India: Special reference to small and medium enterprises. J. Account. Taxation 3(5):105-124.

Habib, Yasir \& Nazir, Muhammad Imran \& Hashmi, Shujahat Haider \& Saeed, Muhammad Bilal (2015). Credit Rating Announcements and Stock return: Evidence from the Banking Sector of Pakistan. Journal of Business Studies Quarterly 24 (2). 
Henderson, V., 2012. Prospect theory, liquidation, and the disposition effect. Manage. Sci. 58 (2), 445-460.

Hens, T., Vlcek, M., 2011. Does prospect theory explain the disposition effect? J. Behav. Finance 12 (3), 141-157.

Hoang, Thi-Hong-Van. Wong, Wing-Keung. Zhu, Zhenzhen (2015). Is gold different for risk-averse and risk-seeking investors? An empirical analysis of the Shanghai Gold Exchange. Economic Modelling 50 (2015) 200-211.

Heutel, Garth. (2019). Prospect theory and energy efficiency. Journal of Environmental Economics and Management. Volume 96, July 2019, Pages 236-254.

Hwang and et al (2010). Predicting issuer credit ratings using a semiparametric method. Journal of Empirical Finance 17. 120-137.

Jang, Jeewon. Kang, Jangkoo. Lee, Changjun (2012). Liquidity Risk and Expected Stock return in Korea: A New Approach. Asia-Pacific Journal of Financial Studies (2012) 41, 704-738

Jecks, Martin. (2016). Understanding and measuring the illiquidity risk premium. Willis Towers Watson.

Jones, Charles P. Investment management. Translation: Dr Reza Tehrani and Asgar Nourbakhsh (2006 - 11th edition). Tehran: Nashr-e Khaz Knowledge. Persian translation

Jorion, P., (2000). Value at Risk: The New Benchmark for Managing Financial Risk. McGraw-Hill, New York, NY.

Kahneman, Daniel. Tversky, Amos (1979). Prospect Theory: An Analysis of Decision under Risk. Econometrica, Vol. 47, No. 2. (Mar. 1979), pp. 263-292.

Marcin, Tomasz, (2009). Application of Data Envelopment Analysis in Credit Scoring, Master's Thesis in Financial Mathematics, Technical Report

Murcia, Flávia Cruz de Souza; Dal-Ri Murcia, Fernando; Rover, Suliani and Borba, José Alonso. The determinants of credit rating: brazilian evidence. BAR, Braz. Adm. Rev. [online]. 2014, vol.11, n.2, pp.188-209. http://dx.doi.org/10.1590/S1807-76922014000200005.

Mwaurah, Isaac. Muturi, Willy. Waititu, Anthony. (2017). The Influence of Financial Risk on Stock return. International Journal of Scientific and Research Publications, Volume 7, Issue 5, May 2017 ISSN 2250-3153.

Omri, A., Zayani, M., Loukil, N. (2004). Impact of Liquidity on Stock Return: An Empirical Investigation of the Tunis Stock Market, Finance and Business Strategies, Social Science Electronic Publishing.

Pengcheng Song, Xinxin Ma \& Zhang, Xuan (2019). The Structural Changes of Liquidity Risk, and Liquidity Risk Premium in China Stock Market. Emerging 
Markets Finance and Trade, DOI: 10.1080/1540496X.2019.1601554.

Petkova, Ralitsa \& Akbas, Ferhat \& Boehmer, Ekkehart \& Genc, Egemen (2010), The time-varying liquidity risk of value and growth stocks, Journal of SSRN

Rockafellar, R.T., Uryasev, S.P., (2000). Optimization of conditional Value-atRisk. J. Risk 2,21-42.

Sadat, Amin. Abbasi, Ebrahim \& Ghalibaf Asl, Hasan. (2020). Dynamic relationships between financial conditions index and stock returns. Iranian Journal of Finance (IJFIFSA). Vol. 4, No.

Sarykalin, Sergey. Serraino, Gaia. Uryasev, Stan (2008). Value-at-Risk vs. Conditional Value-at-Risk in Risk Management and Optimization. Operations research.

Sobia, Q., Arshad, H., \& Szabo, Z. (2015).Financial Risk \& Share behavior.International Journal of Scientific \& Technology Research Vol 4, Issue 4, April 2015.

Tansel, Y. \&Yardakul, M. (2010). Development of a quick credibility scoring decision support system using fuzzy TOPSIS. Expert Systems with Applications, 37, $567-574$

Wang, Huijun, Yan, Jinghua, Yu, Jianfeng, 2016. Prospect theory and the riskreturn tradeoff. J. Financ. Econ. 123 (2), 395-414.

Whitelaw, Robert F. (2000). Stock market risk and return: an equilibrium approach. Econometrica, Vol. 47, No. 2. (Mar. 1979), pp. 263-292.

\section{Bibliographic information of this paper for citing:}

Peymany, Moslem; Erza, Amir Hossein \& Seifi, Farnaz (2020). Asymmetric Reaction of Investors to Market Risk, Illiquidity Risk, and Credit Risk: Evidence from Tehran Stock Exchange (TSE). Iranian Journal of Finance, 4(4), 44-65.

Copyright @ 2020, Moslem Peymany, Amir Hossein Erza and Farnaz Seifi 